\title{
Total Laryngectomy outcome of 36 cases after 5 years at Mosul Centre
}

\author{
Nafi M. Shehab, Youis Sultan, Daoud S. Allos \\ Dept of Surgery, College of Medicine, University of Mosul.
}

(Ann. Coll. Med. Mosul 2008; 34(1): 16-20).

Received: 19 ${ }^{\text {th }}$ Apr 2006; Accepted: $23^{\text {rd }}$ Jan 2008.

\section{ABSTRACT}

Objective: To evaluate results of treating laryngeal cancer by total laryngectomy.

Methods: A prospective study of 36 patients with squamous cell carcinoma of the larynx treated with total laryngectomy over five years period.

Results: The age range of the patients was between 34-72 years with a male to female ratio of $11 / 1$. After five years follow up of patients , $100 \%, 84 \% \& 14 \%$ were free of disease for T2, T3 \& T4 respectively. Results of treating cases at T3 stage seems to be better when surgery preceded radiotherapy than when radiation given before.

Conclusion: Combination of surgery and radiotherapy gives relatively high cure rates if stage of tumour was still within the larynx ( T3 or less). The results of this study shows that this was better when surgery preceded radiotherapy.

$$
\begin{aligned}
& \text { الخلاصة } \\
& \text { الهذف: تهدف هذه الدر اسة لتقييم نتائج علاج ورم الحنجرة الخبيث بعملية استئصسال الحنجرة. }
\end{aligned}
$$

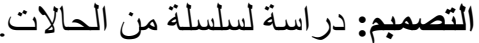

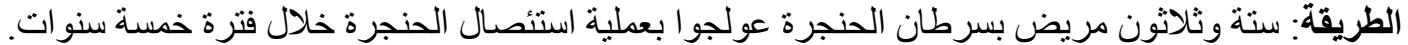

Cancer of the larynx is a particularly important malignancy representing approximately $1 \%$ of all malignancies ${ }^{(1)}$. It share with only few other types of cancer a high rate of cure, which in certain subsites, may reach over $85 \%$ and overall 
exceeds $50 \%{ }^{(1,2)}$. A great responsibility is thus thrown on clinician, because careful evaluation and treatment bring probability of cure.

The first total laryngectomy was performed by Bilroth in 1873 and was not generally accepted because of the high mortality and morbidity at that time. However, Solis \& Cohn, in 1892 improved the technique by diverting tracheal stump to skin. With the advent of radiotherapy in the second decade of twentieth century, the operation became less popular ${ }^{(3)}$. The operation regained popularity after 1940 , as surgical aids were introduced (namely antibiotics, safe anesthesia and blood transfusion) and surgical techniques improved $^{(1,3)}$.

The aim of this study is to evaluate the results of total laryngectomy in treating cases with laryngeal cancer and its complicatios in our center.

\section{Patients and Methods}

Over five years period (1996 -2000), total laryngectomy was carried out by larynx cancer team for thirty - six patients with carcinoma of the larynx without lymph node or distant metastasis at ENT department-Al jumhuri Teaching Hospital. The indication for surgery were $\mathrm{T} 3, \mathrm{~T} 4$ tumours and recurrence after deep X.ray therapy.

Preoperative general investigations were done to all patients and specific investigatios (as C-T scan, MRI or both) was done whenever needed.
Patients' staging was done according to AJC system as it is the system approved in our unit and their numbers were:

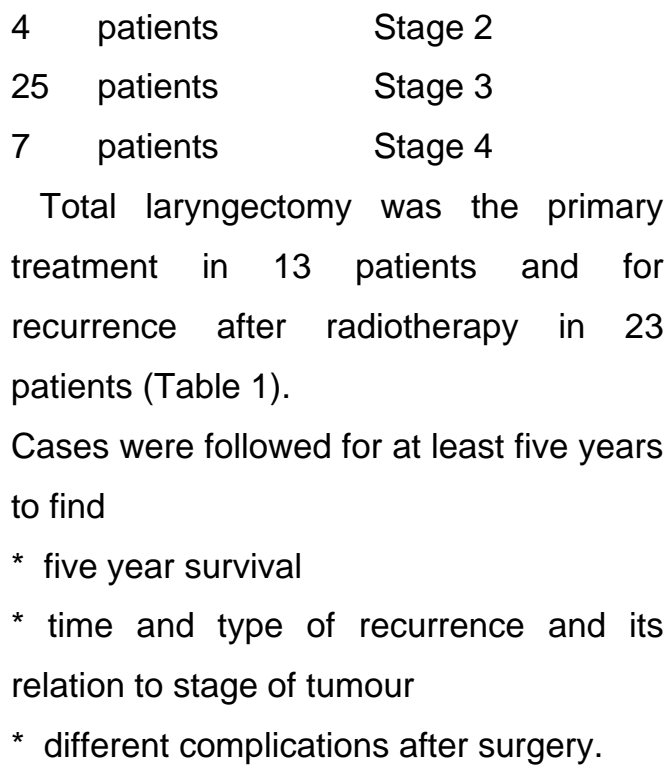

\section{Results}

It is apparent that laryngeal cancer is a disease affecting mainly elderly males. The age range between 34- 72 years. All but three were males. The male to female ratio is $11 / 1$.

Table 2 shows the number of cases who where disease free after five years follow up according to stage. Among the 25 patients with stage 3 tumour, radiotherapy was the initial treatment in 14 cases followed by total laryngectomy for recurrence. In the remaining 11 patients surgery proceeded radiotherapy. The cure rates of both groups are given in table 3 .

The recurrence rates of the disease after surgery were:

Three patients: Cervical lymph node metastasis.

One patients : Liver metastasis

Two patients : Stomal recurrence

Four patients: local pharyngeal and oesophageal recurrence. 
Table 1: Number of operations done before or after radiotherapy

\begin{tabular}{|c|c|c|c|}
\hline Stage & $\begin{array}{c}\text { Surgery as primary } \\
\text { treatment }\end{array}$ & Surgery after radiotherapy & Total \\
\hline T2 & 0 & 4 & 4 \\
\hline T3 & 11 & 14 & 25 \\
\hline T4 & 2 & 5 & 7 \\
\hline Total & 13 & 23 & 36 \\
\hline
\end{tabular}

Table 2: Five years survival

\begin{tabular}{|c|c|c|}
\hline Stage & Total number of cases & Five years survival \\
\hline T2 & 4 & $4 \quad 100 \%$ \\
\hline T3 & 25 & $21 \quad 84 \%$ \\
\hline T4 & 7 & $1 \quad 14 \%$ \\
\hline
\end{tabular}

Table 3: Cure rates for $\mathrm{T} 3$ stage tumours

\begin{tabular}{|c|c|c|}
\hline Type of treatment & Number of cases & Cure rates \\
\hline Radiotherapy followed by surgery & 14 & $1178.6 \%$ \\
\hline Surgery followed by radiotherapy & 11 & $10 \quad 91 \%$ \\
\hline
\end{tabular}

\section{Discussion}

Assessment of relative value of differing treatment methods of laryngeal cancer is not easy ${ }^{(1-5)}$. Adequate conclusions by randomized controlled prospective studies are still lacking, in part as a consequence of difficulty of applications in cancer therapy ${ }^{(1)}$. The two treatment modalities which aim at cure of laryngeal cancer are surgery, radiotherapy or both and the choice between them should be made according to the likely effective control of the cancer, the general health of the patient and the relative consequences of the treatment ${ }^{(6)}$. Radiotherapy has the advantage of vastly reduced morbidity compared with surgery ${ }^{(6)}$. Experience over the last five decades showed that radiotherapy is the treatment of choice for early laryngeal cancer $(T 1 \& T 2)^{(1,6-8)}$. Modren radiation techniques still allow the surgeon to perform partial or total laryngectomy for failures ${ }^{(1)}$.

The treatment of more advanced (T3) lesions are more controversial ${ }^{(1,5)}$. Robin et 
$\mathrm{al}^{(9)}$ showed that T3 glottic carcinoma may be treated by radiation with salvage surgery without any reduction in cure.

Biringham and west midland regional cancer registry, showed that recurrence free rates for T3 glottic cancer was 58\% when surgery was primary treatment and $38 \%$ with radiotherapy ${ }^{(1)}$. Djukie et al compaired results of surgery and radiotherapy in laryngeal cancer especially when the anterior commissure was involved and found results of five - years survival in patients treated by primary surgery were highly more significant in relation to results obtained by radiotherapy of patients.

Bourhis et $\mathrm{al}^{(8)}$ studied results of combined radiotherapy and chemotherapy and concluded that laryngeal preservation is generally not proposed in patients with advanced T2 - T3 lesions or when tumour invades the cartilage or soft tissue of $\operatorname{neck}(\mathrm{T} 4)$.

In our study, patients with T3 tumour managed either with radiotherapy followed by surgery or the opposite and we found that five years survival rate was $78.8 \%$ for the former and above $90 \%$ for the later. It is generally better than studies that used single treatment method (5-11), and averages results of Baskota et $\mathrm{al}^{(12)}$ who achieved $89 \%$ disease - free cases with up to five years follow up and used surgery as primary treatment with radiotherapy in advanced cases.

\section{Conclusion}

Combination of surgery and radiotherapy gives relatively high cure rates if stage of the tumour was still within the larynx (T3 or less). The results of this study shows that this was better when surgery preceded radiotherapy.

\section{References}

1. Hibbert J. Scott Brown's Otolaryngology. $6^{\text {th }}$ Ed. Butterworth's London Vol. of laryngology, 1997: 5-11.

2. Powell $\mathrm{J} \&$ Robin PE . Cancer of the head and neck cancer. Tunbirge Wells: Castle House publications, 1983:3-16.

3. Bailey BJ \& Biller HF. Surgery of the larynx. $1^{\text {st }}$ Ed.W.B. Saunders company, 1985:257-279.

4. Ampil FL Nathan CA Caldito G Lian TF Arstad RF \& Krishnametty RM. Total laryngectomy and posroperative radiotherapy for T4 laryngeal cancer: a 14-year review.Am J Otolaryngol.2004 Mar-Apr; 25(2):88-92.

5. Djordjevic $\vee$ Milovanovic J Petrovic Z Pudvarski Z Petrovic $P$ \& Stankovic $P$ .Radical surgery of malignant laryngeal tumours. Acta Chir lugosol.2004;51(1): 31-5.

6. Roland NJ McRae RDR \& McCoobe. Key Topics in otolaryngology. $1^{\text {st }} \mathrm{Ed}$. Bios Scientific Publishers, 1995;156-160.

7. Bourhis J Wibault P \& Pignon JP. Larynx preservation: non- surgical approaches.Cancer Radiother. 2004 Nov;8 suppl 1:824-8.

8. Robin PE Rockley T Powell D \& Reid A. The survival of cancer of the larynx. Clini Otolaryngol. 1991;(16)193-97. 
9. Djukic V Stankovic P Stenvadic N Janosevic L \& Pavlovic B. Dilemmas and controversies related to cancers of the anterior laryngeal commissure. Acta chir lugsol .2004;51(1):9-12.

10. Ji Wy Du Q Guan C \& Wang DG . Survival analysis of 1115 patients with laryngeal carcinoma. Zhonghua $\mathrm{Er} \mathrm{Bi}$
Yan Hou Ke Za Zhi. 2004 Jan ;39(1)179.

11. Baskota DK Prasd R Sinha BK Amatya RC Bhattaai H \& Guragain RP. Outcome of surgical management of laryngeal carcinoma,a: a 5 year experience. Acta Otolaryngol.2004 Aug; 124(6):739-43. 